\section{Arch T. Dotson}

Arch T. Dotson, professor emeritus of government at Cornell University, died April 6, 2006, at the age of 85. He had been sound of mind and body virtually until the end, teaching until his voice was too weak to be heard. A "country boy" born and bred in Paris, Kentucky, he worked from his early teens on farms managed by his father. Arch left for World War II just short of earning his B.A. from Transylvania College and joined the Army Air Force as a "check pilot," becoming a jock in every war plane up to the B-29. Discharged with the rank of major, the GI Bill got him through his Harvard Ph.D. and a post-doc at the London School of Economics. His entire academic career was at Cornell, beginning in 1950, as a dedicated teacher, serving beyond his retirement as a teacher, and, respectively, as director of Cornell-in-Washington, director of Cornell Abroad, and director of the Cornell Institute of Public Affairs.

Arch's field, his professional identity, was public administration. As was true of so many in this subfield of political science, Arch was not known well as a publishing scholar. He wrote copiously, but for clients, not journals - and for public clients, not corporate or private clients. He did this exclusively for three years (19581960) as a deputy controller of the State of New York. Other clients were, for shorter durations, the UN, the Ford Foundation, and the governments of India, Malaysia, the Philippines, Iran, Jordan, the PRC, Eritrea, and Mexico. Another of his clients was Cornell University. His sevenyear stint as chairman of the department of government (1969-1976) was dedicated to rebuilding the department after the campus crisis of the late 1960s. In the 1980 s, he was instrumental in the founding and success of Cornell-in-Washington (CIW), Cornell Abroad, and the Cornell Institute of Public Affairs (CIPA).

It would be difficult to identify anyone ever associated with Cornell-faculty, administrators, trustees, or alumni-who has left a more important mark on the institution. The government department now holds its own among the top 10 in the nation. CIW and Cornell Abroad became and continue to be models for universities with Washington programs and programs abroad. And CIPA has grown in size and stature among schools, programs, and institutes of public affairs. The Dotson legacy should not-will not-be forgotten.
Arch chose the path of reform, practice, and teaching; and he pursued that path to the very end with integrity, vigor, honor, and distinction. Arch was one of the exemplars of the great tribute to public service made by Louis Brownlow in the title of volume 2 of his autobiography, A Passion for Anonymity.

Milton J. Esman Cornell University Jerome M. Ziegler Cornell University Theodore J. Lowi Cornell University

\section{George J. Graham, Jr.}

George J. Graham died on November 30, 2006, after a courageous battle with cancer. He was 68 years old. George is survived by his daughter, Carmen Michelle Graham Christgau of San Francisco and a sister, Joyce Graham Johnson of Sarasota.

George was born in Dayton, Ohio, and earned his bachelor's degree from Wabash College. He received a doctorate in government from Indiana University in 1965. His honors included a John Simon Guggenheim Memorial Fellowship, the Jeffrey Nordhaus Award for Excellence in Undergraduate Teaching, and the Ernest A. Jones Faculty Adviser Award in the College of Arts and Science at Vanderbilt. He also was awarded a fellowship at the National Humanities Institute at Yale University. George received a Fulbright grant in 1995 to hold the John Marshall Chair in Political Science at the Budapest University of Economic Sciences in Hungary. There he led graduate-level courses on democratization and American institutions and said that he was pleased to have the opportunity to work with colleagues at a time of transformation for democratic institutions. George was a member of the Vanderbilt faculty for more than 40 years, and served as associate dean in the College of Arts and Science from 1986 to 1988 and from 1997 to 2000 . He was also a former chair of the department of political science.

George was a political theorist, with a deep and enduring passion for good arguments and books, whatever their discipline or politics. The evening he left his office for the last time, a Marx reader and a book of Leo Strauss's were open on his desk. Although his first love was for political philosophy, George had a great interest in, and knowledge of, work being done in the other fields of political science and would regularly scold his fellow theorists if he sensed an intellectual narrowness in them. His publications reflect the breadth of his intellectual engagements: American political thought, Rousseau, ethics and public policy, discourse analysis and research methods. Noteworthy among them was his early book on the Methodological Foundations of Political Science (1971) and his articles on the concept of consensus, including "Rousseau's Concept of Consensus" (Political Science Quarterly, March, 1970), "Edmund Burke's 'Developmental Consensus", (Midwest Journal of Political Science, February, 1972), and “The Concept 'Consensus' in Political Theory and Research" (Political Inquiry, 1974). George was also actively involved in the profession, and took great pride in his role in creating the Foundations of Political Theory Section. His concern with concepts and methods in political research led him to co-found and later serve as president of the Committee on Conceptual and Terminological Analysis (later the Research Committee on Concepts and Methods), the very first official research committee to be acknowledged by the International Political Science Association.

George was a teacher through and through. His courses on Marx and on the early moderns were legendary among Vanderbilt undergraduates. But it was as a mentor to graduate students, in all subfields, that George excelled. He had an essential kindness about him, not a saccharine bonhomie but an interest in the intellectual welfare of students. He could be a severe critic of their work, when that was called for, but he never sought to demean or belittle them. His concern for them was repaid in their affection for him. It was a rare hour that one walked by George's office without seeing a graduate student there talking with him.

When we visited George in the hospital, a few days before his death, his principal worry was for his graduate students and undergraduate classes.

As a scholar and teacher, George contributed to the life of the mind, to his colleagues in the profession, and to his students. As an active member of the profession's institutions, George helped secure a lasting and active place for his subfield in the American Political Science Association. And as an administrator here at Vanderbilt, George will be remembered fondly for his devotion to the College and University, expressed most visibly in his 